\title{
Development of service pension policy in Latvia from 1996 until 2016
}

\author{
Inese Upite and Feliciana Rajevska \\ Vidzeme University of Applied Sciences, Latvia
}

\begin{abstract}
The government made a decision to terminate the development of the service pension in 1997. However, during 1998-2016 the scope of service pension beneficiaries was extended. Thereby along with the overall social insurance pension system, the social pension scheme has been established and developed for a certain range of people funded by the state budget - the system of the service pension. The aim of the article is to explore the development of the service pension policy during 1996-2016. To accomplish it, in the framework of the study concepts related to the service pensions and the tendencies of reformation of the service pension schemes were studied. The international practice and the experience of several countries were explored, as well as the analysis of legal acts, policy planning papers and statistics was performed. The purpose of the service pension has changed and diversified, moreover, the issues regarding the service pension coverage are promoted by a group of politicians, escaping a wider discussion in public and even in the government.
\end{abstract}

Key words: service pension, pension policy, professional capacity.

\section{Introduction}

Several concepts are used regarding the description of service pensions (for the purpose of Latvian legislation and policy planning documents) in the international research practice. One of the terms broadly used is a "pension system for civil servants" or "civil servants' pensions". This could be linked to the historical development of pension rights, namely - civil servants and other public-sector employees - in the military, education, publicly owned enterprises etc. - were often among the first groups of workers to be covered by government-sponsored pension schemes (Palacios, Whitehouse 2006: 7). Other term used in relation to the service pensions is "special pension schemes" or a "pension for public sector". These terms have been used discussing both the pension schemes for public sector employees and separately civil service pension schemes.

In Latvia the regulation and provisions of the service pensions initially were extended to pensions provided only for employees (officials) who were employed in a kind of work that is accompanied by a loss or decrease of professional capacity for work before reaching the general retirement age, which hinders continued work in that profession or position. From 1996 the new state pension system is being established that is based on social insurance contributions done by an employee and an employer (National Defined Contribution System). In 1997 the decision on the termination of further development of the service pension was made, thus the service pension guarantees were provided only for the military staff and officials in the system of the Ministry of the Interior. However, during 1998-2016 the scope of the service pension beneficiaries was extended providing service pensions for part of employed in public sector [21]. As a result, along with the overall social insurance pension 
system, the service pension system funded by the state basic budget (and not connected with the amount of person contributions) has been established and developed for a certain range of people.

\section{Concept of service pension}

The international research practice uses several concepts regarding the service pensions. One of the terms broadly used is "pension system for civil servants" or "civil servants pensions". This can be linked to the historical development of pension rights, namely - civil servants and other public-sector employees - in the military, education, publicly owned enterprises etc. - were often among the first groups of workers to be covered by government-sponsored pension schemes [3].

According to the Discussion paper of World Bank "Civil-service pension schemes around the world" the rationale for providing pensions for government employees was somewhat different from that behind the creation of national pension schemes: (1) securing the independence of public servants; (2) making a career in public service attractive; (3) shifting the cost of remunerating public servants into the future; and; (4) retiring older civil servants in a politically and socially acceptable way [3].

Other term used in relation to the service pensions is "special pension schemes" or a "pension for public sector", which covers already wider range of staff as the "civil servants scheme". As mentioned in the research project "Social Structure, Social Security, and the Social Position of the Public Service Sector: European Models and National Case Studies" both terms have a close historical relationship - the alimentation of state servants became a model worth being imitated by other occupational groups as early as the 19th century [4].

In several international research documents the service pension is entitled by the concept "special pension schemes" and it refers to both pensions for employees in the public sector and particular civil service pension schemes. According to the OECD "Working paper 2, Public Sector Pensions and the Challenge of an Ageing Public Service", the pension scheme is seen as an important component of remuneration. In some countries, the provisions for public sector pensions are closely linked to the notion of a legally distinct body of staff - the "civil service". It is maintained that it is the state's duty to ensure that this core of employees enjoy a certain standard of living in retirement in exchange for the obligations placed upon them in terms of service and loyalty [2].

According to the OECD Pensions Outlook 2016 in most OECD countries certain categories of workers in the public sector are covered by an independent pension system. This most commonly applies to the military, fire-fighters and the police. For these groups, which are exposed to increased occupational hazard, retirement ages are set earlier than for private sector workers, even in those countries where all groups fall under the same scheme. Other occupations typically covered in separate schemes include teachers and judges. The largest schemes, however, are those that cover local government employees and civil servants (central or federal government employees) [5].

OECD Pensions Outlook 2016 argues on institutional arrangements for pensions covering civil servants vs. private sector workers, and civil service pension schemes are split in the following categories: (1) fully integrated (Czech Republic, Poland, Portugal); (2) separate, but similar benefits (Denmark, Finland, Sweden); (3) fully integrated with top-up (Canada, Norway, United Kingdom); (4) entirely separate (Belgium, France, Germany) [5].

Over the last 20 years, however, many countries have closed civil service pension schemes for new entrants and enrolled workers entering the civil service in the main private sector scheme. Still a number of OECD countries maintain a dual system with sometimes large 
differences in rules and entitlements for civil servants compared to those working in the private sector [2].

Within the public sector, the majority of pension schemes remain of defined-benefit type, though their generosity has been reduced in many countries, through either increasing contributions or reducing the associated accrual rates. The reforms done to the pension systems within the public sector can be classified under a number of different headings: (1) increase in pension age; (2) reduction of pension generosity or increase in career length; (3) increase in contributions; (4) integration of civil-service within the general state scheme (5) restriction to early retirement [5].

\section{Explanation and understanding of the service pension concept in Latvia}

To gain insight in the nature of the concept of service pensions and its explanation in Latvia, at first the national laws shall be examined that, moreover, provide the historical dynamics of the concept explanation. According to Law on State Pensions adopted on November 29, 1990, the service pension is granted to citizens working in certain professions which after reaching a certain length of service are related to the loss of professional skills or social danger (Law on State Pensions, 29.11.1990). Similar objective of the service pensions is included in Law on the Service Pension of State and Local Government Professional Orchestra, Choir, Concert Organisation, Theatre and Circus Artists and the Allowance for Creative Work of Ballet Artists. According to the Section 2, the right to a service pension is prescribed in light of the fact that working in these professions over a period of time is connected with the loss of one's professional skills before reaching the age determined for granting of an old-age pension [17].

Different objective of the service pensions appears in the annotation of Law on Service Pensions for Officials of the Constitution Protection Bureau, where it is specified that the draft of legal act is aimed at provision of social guarantees for officials of the Bureau [14]. While in Law on Service Pensions for Diplomats adopted by Parliament on November 2, 2006, there is another relevant aspect of the service pensions, namely, the Law provides for the right to receive the service pension aimed to facilitate stability and consistency of the diplomatic and consular service [16]. Therefore the objectives of the service pensions are different despite the fact that both draft laws have been adopted almost at the same time.

Explanations and compilations of views on the objectives of the service pensions can also be found in the judgments of the Constitutional Court of the Republic of Latvia, concluding that the following groups of employees can be divided, for whom particular social guarantees have been defined: (1) the nature of the service or the professions are associated with the reduction or loss of skills when they reach a certain age or profession after a certain period of time (accumulating a certain length of service); (2) the person concerned complies with the relevant services of the state which differs significantly from the working conditions of persons employed on the basis of a civil legal contract. During the service, a person is subject to certain significant restrictions (service regulations, etc.), they are obliged to participate in the performance of the service under unexpected, sometimes dangerous conditions. In this case, the service pension, on the one hand, compensates for the early loss of capacity for work, but, on the other hand, serves as a compensation for the restrictions during the service, irrespective of whether they are or are not caused by premature labour capacity reduction; (3) the service pension indirectly becomes as "deferred compensation" for impeccable service over a long period of time and contributes to the quality of service and institutions, particularly in the anticorruption aspect $[8,10]$. 


\section{Criteria for service pensions}

At present, the conditions for granting of a service pension and service pension beneficiaries can be relatively divided into two categories. The first category includes persons who have been granted a service pension, or who may be eligible for the service pensions from the state social insurance special budget [22]. Criteria for granting the service pension and the profession breakdown were largely derived from the former USSR legislation according to which the employed in some professions performing a job with increased risk and loosing professional skills, after a certain period of time could request a service pension from a significantly earlier age [9]. Persons who up to January 1, 1999, worked in respective professions for not less than three quarters of the insurance period that according to the law "On Service Pensions" is necessary for granting of the respective service pension, shall retain the right to a service pension if it satisfies the other provisions prescribed in referred law.

Analysing the legal framework, it can be concluded that the retirement age for most categories are similar and it ranged from 45 years to 55 years (retirement age for the service pensions for men is 5 years higher than for women). All categories [23] have almost the same conditions in respect of criteria for the insurance periods, namely, women have at least 20 years of insurance experience, men -25 years. The conditions of special service length are slightly different, depending on the specific nature of work and the level of complexity, varying from 7 years to 20 years, for example. With regard to existing conditions, a number of the service pension beneficiaries is gradually decreasing.

Since 1999, when further determination of the insurance length of referred categories was interrupted, both representatives of trade unions and individual parliamentarians have repeatedly tried to restore the right to a service pension for all categories of persons or only certain professions or supplement the scope of service pension recipients.

The second category consists of the service pensions financed from the national budget to which the following categories of persons are entitled: the military, employees of the Ministry of Interior with special service ranks, prosecutors, judges and the Ombudsman, diplomats, state and local government professional orchestra, choir, concert organisation, theatre and circus artists, employees of the Corruption Prevention and Combating Bureau and employees from the Constitution Protection Bureau.

The service pensions shall be allocated on the basis of time worked in the specific profession or position, the term of service and the age of the person.

In the light of the criteria set out in regulatory enactments, the retirement age for the service pension recipient category ranges from 38 years for some of the cultural sector employees to 55 years for diplomats and cultural workers. Conditions for the necessary length of service for granting of a pension for most of the categories are similar and ranges from 10 to 30 years. The amount of service pension for most of the categories is $55 \%$ of the average monthly salary of a person, as a result the amounts of the service pensions in 2016 range from 496 euro for employees of interior institutions to about 1950 euro for judges [21].

Disbursement of the service pension shall be suspended if a person continues to work in a profession, which gives the right to receive the service pension. But there are exceptions as well, for example, for the employees of interior institutions the granted service pensions shall cease if a recipient of the service pension again enters into service of the Ministry of Interior or the Ministry of Defence and the authorities of service which entitle to a service pension.

\section{Policy planning papers and reforms}

The Ministry of Welfare has elaborated several policy planning papers (informative reports and concept papers) aimed at analysing practices of granting the service pensions, to evaluate 
granting criteria of the service pension and the possibility to review the beneficiaries of service pensions during the period from November 2005 to the end of 2013 [8-10]. None of the policy planning papers submitted to the Cabinet has been reviewed, and the decision on specific actions for the service pension system review has not been taken.

Last Concept Paper "On the granting of a service pension" in 2013 was elaborated following task by the Cabinet of Ministers in cooperation with institutional stakeholders. The Concept Paper anticipated to define a framework of the service pension, namely, a service pension is granted to persons whose service/work is related to the provision of public internal and external security and persons performing important state services which differ significantly from the working conditions of persons employed on the basis of a civil legal contract, as well as a person is subject to certain significant restrictions and is involved in the performance of the service under unexpected, sometimes dangerous conditions [7]. It was also planned to raise the retirement age and to review separate service pension granting criteria. The Concept Paper was not reviewed in the Cabinet. With the change of the government it has been acknowledged that the Concept Paper has lost its topicality.

\section{Discussion}

In 1996, while building a pension system based on the principles of social insurance, as well as implementing the reform of the general social security system, which was completed in 1998, a political decision was taken to stop further determination of the length of insurance entitling to a service pension. The decision was implemented on November 20, 1997, when the Saeima (the parliament) adopted the amendments to the Law "On State Pensions" [7]. At the same time the transitional arrangements were stipulated in the regulations (persons who have until January 1, 1999, worked in the respective professions for not less than threequarters of the insurance period, which in accordance with the Regulations "On Service Pensions" is required for granting the relevant service pension, retain the right to the service pension, provided that the other requirements laid down in the previously mentioned regulations are observed [13]) in order to ensure the principle of legitimate expectations maintaining the service pension rights for part of people. The developed system of social insurance and the pension system provided a range of support mechanisms in relation to the loss of professional skills: (1) a possibility to claim early retirement; (2) insurance remuneration in case of an occupational disease, which, moreover, is paid in full if the person continues to work; (3) disability pension in a situation when a person has a decreased ability to work due to health problems; (4) a possibility to participate voluntarily or through employer in a private pension scheme. At the same time, the social security system also envisages lifelong learning and retraining opportunities.

Through the social security system, a sufficient support mechanism was created for people who have lost the ability to work in a particular profession, in order to compensate for the termination of further development of the service pension system anticipated by the legislators. Nevertheless, the circle of service pension recipients gradually expanded rather than decreased.

Analysing the dynamics of regulations and parliamentary documents of the period from 1998 to 2016, the conclusion is that out of all categories of people who were granted the service pension rights in this period, only in two cases (judges, public security institutions) the issue was on the government agenda (reviewed by the Cabinet of Ministers). The other categories of people acquired the service pension rights following the initiative of a group of MPs. The first categories of people whose service pension right initiatives were promoted by politicians were prosecutors and culture industry employees [7]. It was followed by the Regulations on the Corruption Prevention and Combating Bureau Service Pensions, which 
was promoted by a group of MPs. Service rights of diplomats and employees of emergency medical service were ensured with the support of the parliamentary commissions, and in some cases the proposal appeared unexpectedly - just before the third final reading. In addition, as shown by the documentation, the initiators of law in many cases were not a trade union or an interest group, but a particular department of a Ministry [7, 8]. Thus, it proves the privileged role of some politicians and departments and their impact on the service pension policy development.

With new categories of people obtaining the service pension rights, also the aim and purpose of these pensions expanded. Originally, the main aim of the service pension was to provide financial support to people who are employed in occupations associated with certain early loss of professional skills or abilities. With the broadening range of people, also the nature of the service pension changed. Namely, the service pension was perceived as "full-fledged social guarantee when reaching the retirement age" [7], "guarantee for the fact that the employee has been loyal to the state" [7], "deferred pay" for flawless service" [15], low salary solution [18-20]. The study of the documents shows that the expansion of the service pension rights continues - currently on the agenda of parliamentary commissions is the service pension bill for the State Probation Service, and the employees of the municipal police and some education representatives are actively struggling for their rights to theservice pension.

Thus, at the moment the aim and nature of the service pensions is much closer to the way these special pension schemes are identified in other countries, and their purpose is to ensure the independence of the civil service, as well as to ensure a certain standard of living of the public sector employees [2]. However, there is one significant difference; namely, while in other countries civil servant contributions tend to beat least at the level of their private sector counterparts [5], in Latvia the service pensions are fully financed from the state budget. It means that neither the employer, nor the employee contributes - when reaching the retirement age; the state provides a service pension in the defined amount from the previously received salary, which is essentially a defined benefit pension [2] in a situation when a national defined contribution pension is officially in place in Latvia. Thus, according to the OECD division [5], Latvian service pension scheme can be considered as fully integrated, since any employee (also in the professions entitled to the service pension) is subject to the general pension insurance - through social security contributions, a capital is accumulated for the old-age pension of a person. The service pension scheme is only as a supplementary scheme for certain categories of public employees and subject to its terms, does not comply with the understanding in the international practice on special pension schemes [2, 3, 5].

In addition, according to the current legislation, the old-age pension amount shall not be less than previously allocated service pension, since after granting the old-age pension the payment of the service pension is renewed, reducing it by the amount of the old-age pension [14-17]. Thus, some categories of employees are able to not only retire at a significantly younger age (compared to the general retirement age), but the state pays in addition to their old-age pension from its budget, providing a very generous income replacement in the old age. In 2016 the average amount of the allocated service pensions was 569.81 euro (diplomats - 1579.45 euro; judges - 1950.97 euro, internal affairs employees - 496.37 EUR) [21], while the average old-age pension in Latvia was 319.95 euro. According to data of the Ministry of Welfare, the number of service pension beneficiaries is gradually increasing [8, 24].

Looking at the reform dynamics of the special pension schemes in the public sector in other countries - raising the retirement age, reducing the planned replacement level, extending the average service period in the pension calculation formula, as well as the introduction of or increase in contributions of participants (Palacios, Whitehouse, 2006: 73), 
the conclusion is that they largely coincide with the proposed initiatives of the developed policy planning documents in Latvia [8-11]. But studying the dynamics of policy planning documents in the area of the service pension policy, it must be concluded that none of the documents has been addressed in the Cabinet of Ministers. As a result, the service pension granting criteria have not changed in Latvia since these regulations were initiated for specific employment categories; they were even excluded from the requirement for raise of the retirement age, while the general retirement age criteria have been changed several times [13].

\section{Conclusions}

During the period from 1996 to 2016, the service pension system in Latvia has developed expanding from the support to some employment categories in relation to the loss of professional skills in a particular profession, to the "full-fledged social security guarantee upon reaching the retirement age" [7], and "ensuring service stability" [6]. Thus, at the moment the service pension objective is closer to the one in special and civil service pension schemes in other countries. The research of international practice in the area of special pension schemes leads to the conclusion that the Latvian service pension scheme according to the OECD institutional arrangements for pensions covering civil servants vs. private sector workers can be considered as fully integrated [5].

Similar special pension schemes are provided in a number of countries in the world, in some countries these schemes have very old historical traditions and individual system conditions, including very attractive conditions that cannot be copied in another country in another context [1]. Studies on the dynamics of special pension schemes in other countries have shown that the reform issues of such schemes are on the agenda of many countries. A number of countries have completely done away with separate pension regimes for public sector workers. Others have sought to limit the special features of public sector schemes and make them more like the schemes available for the general population [2]. While in a number of countries special pension schemes are reformed, increasing pension age, reducing pension generosity, increasing the career and contributions, the service pension scheme in Latvia tend to be gradually expanding, without any reforms.

As the cause of such expansion could be the blurry aim and substantiation of service pension. It gives the opportunity for departments using their impact and political support to develop the service pension policy according to their interests. The dynamics of the regulations on the service pension policies show that the possibility of the system extension was based on the political support, and initiatives for granting the service pension rights are promoted bypassing the government's agenda. Thus, it greatly narrows down the process of agreement with other institutions, andthe possibilities of expressing opinion by social partners and the public.

\section{References}

[1] F. Eich, Social Sci. Res. Network 30 (2009) retrieved: 21.04.2013, available: http: // unpan1.un.org/intradoc/groups/public/documents/apcity/unpan047398. pdf

[2] J. Kings, E. Turkisch, N. Manning, Public Sector Pensions and the Challenge of an Ageing Public Service, 33 (OECD Working paper 2, 2007), available: https://www. oecd.org/gov/pem/38199046.pdf 
[3] R. Palacios, E. Whitehouse, Civil-service Pension Schemes Around the World (The World Bank, 2006), available: http://documents.worldbank.org/curated/ en/546181468147557849/Civil-service-pension-schemesaround-the-world

[4] F. Rothenbacher, The Welfare State of the Civil (or Public) Servants in Europe: A Comparison of the Pension Systems for Civil (or Public) Servants in France, Great Britain, and Germany 63 (Working Papers Nr. 74, 2004) Mannheimer Zentrum für Europäische Sozialforschung

[5] OECD Pensions Outlook 2016 (OECD Publishing, Paris, 2016) Vol. 186

[6] F. Rajevska, L. Romanovska, - Latvia: both sides of economic recovery success story in "Challenges to European Welfare Systems" edited by Klaus Schubert, Palloma de Villota, Johanna Kuhlman (Springer, 2016), p. 473-496

[7] I. Upīte, Service Pension policy development in Latvia from 1996 till 2012, 93, Globeedite, 2014, available: https://www.globeedit.com/catalog/search Project of Conception on Service Pension Granting, Ministry of Welfare 24 (2013)

[8] Conception on Sustainability of Social Insurance System 49, Ministry of Welfare, 2010, available in the website of the Cabinet of Ministers, section: policy planning data base

[9] Project of Conception on Service Pension Granting 19, Ministry of Welfare, 2006, available in the website of the Cabinet of Ministers, section: policy planning data base

[10] Informative Report on Service Pension Granting Practice 10, Ministry of Welfare, 2005, available in the website of the Cabinet of Ministers, section: policy planning data base

[11] Constitutional Court Judgement of April 21, 2010, case No 2009-86-01, available: http://www.satv.tiesa.gov.1v/en/

[12] Law On State Pensions, 02.11.1995, Latvijas Vēstnesis Nr. 182, 23.11.1995, available: http://likumi.lv/doc.php?id=38048

[13] Law On Service pensions for Officials of the Office for the Protection of the Constitution 18.12.2003, Latvijas Vēstnesis Nr. 2, 07.01.2004, available: http://likumi.lv/doc . php?id=82744

[14] Law On Service Pensions for the Justices 22.06.2006, Latvijas Vēstnesis Nr. 107, 07.07.2006, available: http: //likumi.lv/doc .php?id=139370

[15] Law On Service Pensions for the Diplomats 02.11.2006, Latvijas Vēstnesis Nr. 183 (3551), 15.11.2006, available: http://likumi.lv/doc .php?id=147918

[16] Law on the Service Pension of State and Local Government Professional Orchestra, Choir, Concert Organisation, Theatre and Circus Artists and the Allowance for Creative Work of Ballet Artists, Latvijas Vēstnesis Nr. 106, 29.07.2004, available: https://likumi.lv/doc.php?id=90806

[17] Annotation of the Law On Service pensions for Officials of the Office for the Protection of the Constitution 18.12.2003, Latvijas Vēstnesis Nr. 2, 07.01.2004, available: http://likumi.lv/doc $\cdot$ php?id=82744

[18] The protocol No 15 of Social and Employment Matters Committee of the Parliament of Republic of Latvia, 18/02/2004, unpublished

[19] The protocol No 44 of Social and Employment Matters Committee of the Parliament of Republic of Latvia, 31/05/2005, unpublished

[20] Data of State Social Insurance Agency, available: http://www.vsaa. lv/lv/budzets-un-statistika/statistika

[21] Employed in public sector: prosecutors; judges; State and Local Government Professional Orchestra, Choir, Concert Organisation, Theatre and Circus Artists; 
Diplomats; Officials of the Corruption Prevention and Combating Bureau; Officials of State security institutions; Employees of the State Emergency Medical Service

[22] Persons to whom the service pension is granted in transitional period in accordance with by-law "On Service Pensions" and Law "On State Pensions"

[23] The aviation sector, railway employees, maritime, river fish industrial fleet, public transport, theatres, the circus, association of artists

[24] Expenditures for service pension in 2016 was about 33 milj. (about 7 thousand persons) 